$\operatorname{COCOS}(1998-99), 13,21$ - 29

Printed in Sri Lanka

\title{
STEM BLEEDING INCIDENCE OF COCONUT IN HAMBANTOTA DISTRICT
}

\section{H T R Wijesekara, C N K Rajapakse, L C P Fernando, C K Jayasinghe*, S P Manoher and K F G Perera}

Coconut Research Institute, Lunuwila, Sri Lanka.

* Department of Plant Pathology, Rubber Research Institute, Dartonfield, Agalawatta, Sri Lanka.

\begin{abstract}
A heavy incidence of stem bleeding in coconut palms was reported during 1995 in Hambantota District, Sri Lanka. Palm to palm survey and laboratory investigations were conducted to determine the incidence, distribution, and cause of the epidemic. The survey revealed that $10 \%$ of the palms in the district was affected. The stem-bleeding incidence was higher in palms closer to water bodies and irrigation channels in the area. The investigations were unable to establish the cause of stem bleeding. The distribution pattern of affected palms suggests that irrigation water may cause stem bleeding and predispose palms to the infection by Ganoderma sp. The fungus Ganoderma, which causes bole and root rot disease of coconut was consistently isolated from the palms with fruiting bodies, and authenticity of the pathogen was proved by the International Mycological Institute, UK. Further studies are necessary to determine the role of water bodies in predisposing the palms to the disease.
\end{abstract}

\section{INTRODUCTION}

Hambantota District which is an important coconut producing area, accounts for nearly $5 \%$ of total 440,000 ha under coconut in Sri Lanka. In the district, coconut is mainly grown as a home garden crop. Although, the area was free from serious disease epidemics in the past, an epidemic of stem bleeding was reported to be spreading during 1995. Majority of the affected palms were weakened by this condition and died.

The initial and most conspicuous symptom of the affected palms is oozing out of a reddish brown viscous liquid from the base of the palms, sometimes extending up to $5-6 \mathrm{~m}$ on the trunk. Subsequently, yellowing and diminishing of the crown, tapering of the trunk, production of fewer and 
elongated nuts occur followed by the formation of bracket like fruiting bodies of the fungus at the base of the palms. Occasionally, decaying of palm bases were accompanied by hollow boles. The fruiting bodies differ in size and shape, but with a reddish brown lacquer coloured upper surface and off-white lower surface.

Preliminary observations revealed that some of the affected palms show all these symptoms but majority had only stem bleeding. The symptoms are similar to those produced by two pathogens of coconut palms, Ceratocystis paradoxa (Goonawardena, 1995) and Ganoderma spp. (Peries, 1974). Therefore, a detailed study was undertaken to investigate the incidence and distribution pattern of stem bleeding in Hambantota District with emphasis on categorizing affected palms on the basis of the symptoms expressed by them. Further, investigations were carried out to determine the causative agent of each category of palms.

\section{MATERIALS AND METHODS}

\section{Survey}

A survey was carried out during August to September 1996 to investigate the distribution and incidence of stem bleeding condition in Hambantota district. The lists of affected lands were obtained from the Coconut Development Officers (CDO) of the district. A public awareness campaign was conducted in the area with the assistance of Divisional Secretariat and Coconut Cultivation Board to identify any other affected lands. In the affected lands a palm to palm survey was carried out with the assistance of CDO and Goviniyamaka of the area. Symptoms of each palm were recorded and palms were marked for easy identification and future reference. Two selected locations were mapped (Maps 1 and 2) to illustrate the distribution of affected palms and their position with respect to the surrounding environment.

Water samples were obtained from various water sources in the Hambantota district and analyzed for different nutrients to investigate whether stem bleeding is correlated with nutrient levels in water bodies.

\section{Laboratory Investigations}

To determine the association of fungi with the affected palms, samples were taken from, the bark of the bleeding patches, stem tissues beneath the bleeding patches $(1 \mathrm{~cm}$ deep) and dead root of the palms. Samples were also collected from the bracket-like fruiting bodies attached to the trunk bases of affected palms. One hundred and seven palms, which were showing only 
bleeding and 125 palms with bleeding and brackets were sampled. Samples were sterilized in 5\% calcium hypochlorite solution for $3-5$ minutes, washed thrice in sterilized distilled water and plated on malt extract agar (MEA) and Ganoderma semi-selective medium (GSM) (Ariffin et al., 1991). Eight pieces of the same sample were placed in one petridish. Cultures were incubated at room temperature $\left(25-30^{\circ} \mathrm{C}\right)$ for 5 days prior to microscopic observation. Observations on growth pattern of the mycelium, morphology and reproductive structures were made. Isolated fungi were sent to International Mycological Institute (IMI), U.K. for authentication.

Eight coconut seedlings were inoculated with the fungal culture isolated from palms with bleeding and brackets to test the pathogenecity. Inoculated seedlings were kept in a green house and watered at four-day intervals. Seedlings were uprooted after six months of inoculation and dead roots were cultured on GSM to re-isolate the fungus.

\section{RESULTS AND DISCUSSION}

\section{Survey}

Stem bleeding prevailed in Ambalantota, Beliatta, Netolpitiya, Tissamaharamaya and Weeraketiya CDO's ranges in the Hambantota District at an average incidence of $10 \%$. The highest number of holdings was affected in Ambalantota CDO range (Table 1). Also two adjoining districts Matara and Ratnapura had affected palms in Dickwella and Embilipitiya CDO ranges respectively (Table 1).

According to the symptoms, affected palms can be categorized into two groups i.e. palms with stem bleeding starting from the base and gradually extending towards the crown and palms with basal stem bleeding or stem bleeding extending towards the crown and associated with decaying of basal stem and /or fungal fruiting bodies (bracket like structures) at the base.

Both categories of palms expressed withering and premature drying of lower fronds, reduction in nut production, tapering and final death of the palm. Majority of affected palms (89.8\%) had bleeding only (Table 1).

Affected palms were in a wide range of soil types. The palms, which showed extensive stem bleeding were mainly confined closer to a source of water such as river, irrigation channels or paddy fields (Maps 1\&2). The palms away from a water source were apparently healthy. This indicated that there is a marked relationship between sources of water and disease distribution. Further, there were two special features in the irrigation system in the area. The water was highly saline (Table 2) and water level fluctuated 
towards the end of the season. High nutrient contents were reported from water sources where there were more affected palms. Highest nutrient content was observed in Chitrakala Estate where more than 500 palms were affected. This land is surrounded by lagoon from three sides and the other side by sea. Chloride ion concentration does not seem to affect stem-bleeding incidence, as there was considerable amounts $(42.6 \mathrm{ppm})$ in the water from a disease free area, Thimbolketiya bridge.

Table 1. Incidence of stem bleeding in different Coconut Development Officers' ranges, in the Hambantota District

\begin{tabular}{|c|c|c|c|c|}
\hline \multirow[t]{2}{*}{ CDO range } & \multirow{2}{*}{$\begin{array}{l}\text { Holdings } \\
\text { surveyed }\end{array}$} & \multirow{2}{*}{$\begin{array}{l}\text { Extent } \\
\text { surveyed } \\
\text { (Ac) }\end{array}$} & \multicolumn{2}{|c|}{ No of palms with symptoms } \\
\hline & & & Bleeding only & $\begin{array}{l}\text { Bleeding + } \\
\text { Brackets }\end{array}$ \\
\hline Ambalantota & 375 & 602.0 & $2988(89)$ & $364(11)$ \\
\hline Beliatta & 10 & 22.5 & $58(97)$ & $2(3)$ \\
\hline Netolpitiya & 10 & 25.8 & $96(99)$ & $1(1)$ \\
\hline Tissamaharamaya & 8 & 16.8 & $79(100)$ & $0(0)$ \\
\hline Weeraketiya & 2 & 54.0 & $18(100)$ & $0(0)$ \\
\hline Dickwella & 1 & 1.0 & $1(100)$ & $0(0)$ \\
\hline Embilipitiya & 5 & 4.0 & $13(100)$ & $0(0)$ \\
\hline
\end{tabular}

Percentage of the disease incidence in affected lands in each CDO range is given in parenthesis.

Almost all the lands affected were situated close to a source of water such as river, irrigation canal, lake or paddy field. This result excludes two large estates Chitrakala and Dehigahalanda affected by Ganoderma root and bole rot disease. In Chitrakala Estate the disease was first reported in 1972 and there were over 500 diseased palms in 150 acre of land.

Nitrogen concentration also has a direct correlation with the disease incidence and the highest concentration was in the water samples collected in the severely affected land. Extremely high sodium ion concentration was detected in Chitrakala Estate while it was low in water from the disease free area.

The weedicides and inorganic fertilizer applied to the paddy fields could be washed away with drainage water and could weaken the coconut roots which are exposed to them. Salgado (1942) reported that stem bleeding in coconut could be caused by physiological factors such as absorption of high fertilizer'doses and excessive amount of water. Imbalances in nutrition could 
cause stem bleeding in coconut palms, especially at low nitrogen and high phosphorus levels (Neelakanthan Potty et al., 1978).

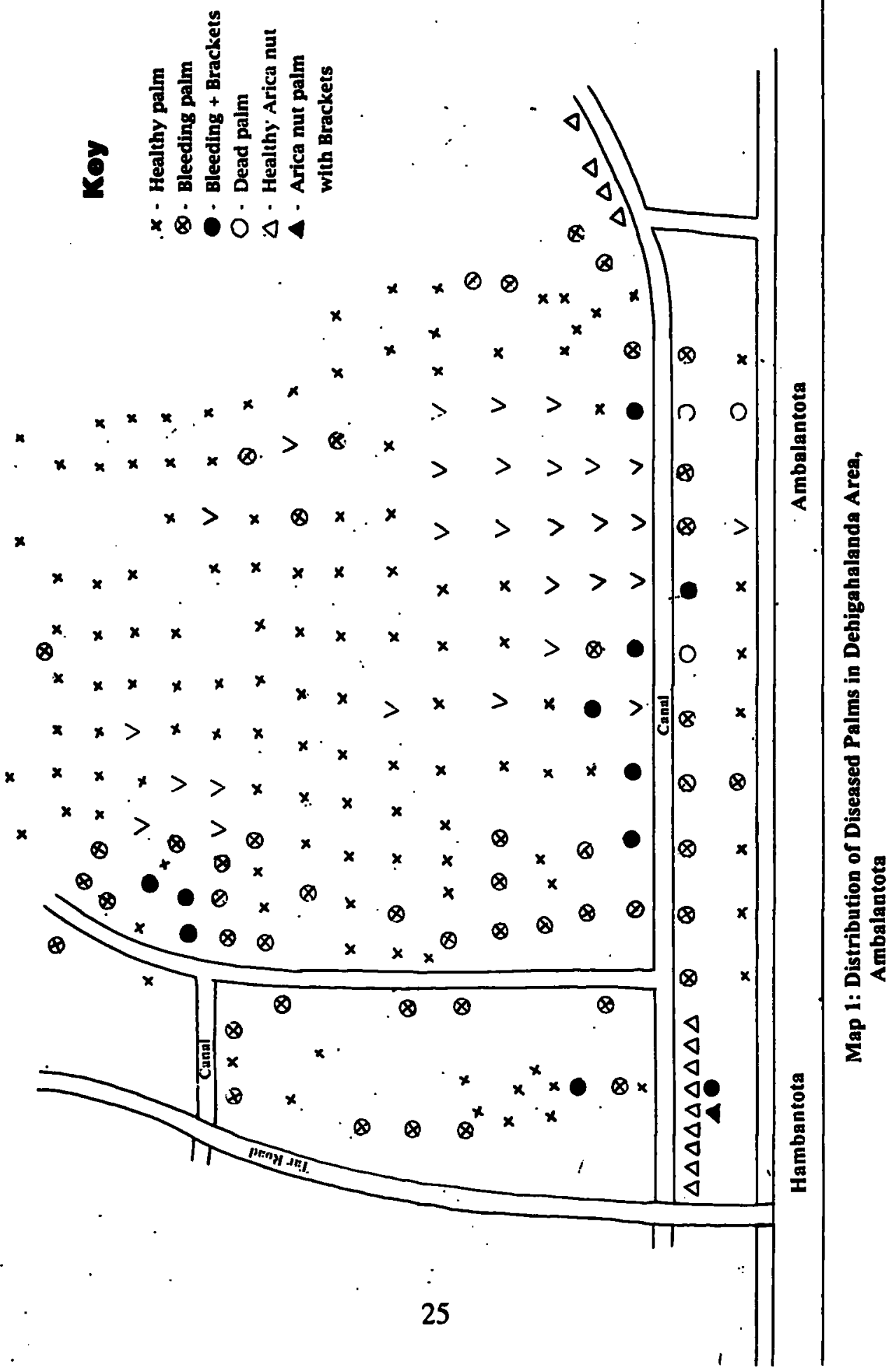




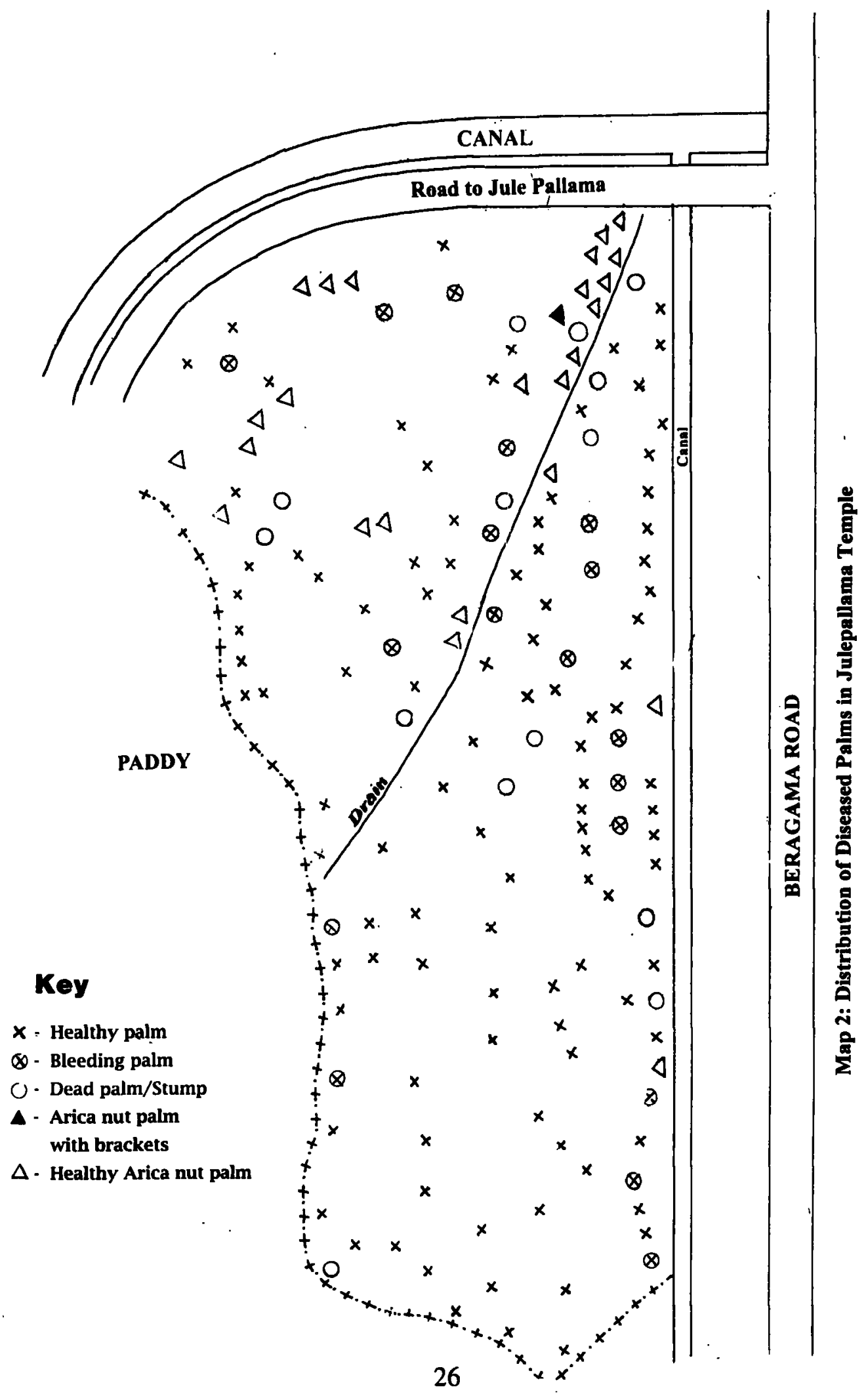


Table 2. Nutrient concentration in water samples collected from different locations of the irrigation system in Hambantota District during paddy growing season

\begin{tabular}{|c|c|c|c|c|c|c|}
\hline \multirow[t]{2}{*}{ Source } & \multicolumn{6}{|c|}{ Nutrient concentration $(p p m)$} \\
\hline & $\mathbf{N}$ & $\mathrm{K}^{+}$ & $\mathrm{Ca}^{+2}$ & $\mathrm{Mg}^{+2}$ & $\mathrm{Na}^{+}$ & ${ }^{*} \mathrm{Cl}^{-}$ \\
\hline Walawe river & 1.348 & 2.06 & 16.7 & 6.23 & 10.50 & 46.15 \\
\hline Koggalu ara & 1.191 & 3.69 & 31.9 & 29.70 & 57.30 & 39.05 \\
\hline Liyangastota anicut & 0.784 & 3.05 & 25.6 & 10.40 & 19.00 & 28.40 \\
\hline Dehigahalanda estate & 2.036 & 8.40 & 40.9 & 47.00 & 223.00 & 17.75 \\
\hline Chitrakala estate & 12.642 & 157.80 & 248.5 & 192.80 & 1517.50 & 44.38 \\
\hline Mamandala lake & 0.940 & 2.74 & 40.2 & 16.80 & 43.70 & 56.80 \\
\hline Thimbolketiya bridge\# & 0.472 & 1.52 & 13.1 & 3.12 & 6.24 & 42.60 \\
\hline
\end{tabular}

* - concentration $\mathrm{mg} / \mathrm{l} \quad \#$ - disease free area.

\section{Laboratory investigations}

Several fungal species were isolated at different tissues from affected palms (Table 3). Ganoderma sp., which is the causal fungus of root and bole rot disease in coconut was isolated from the dead roots and decayed tissues underneath the basal bleeding patches of the palms with bleeding and from brackets. The IMI, UK confirmed the identification of Ganoderma fungus (IMI number 375255) to the generic level. Only one seedling out of eight inoculated with Ganoderma sp. showed infection.

Table 3. Fungi isolated from various tissues of stem bleeding palms with and without brackets

\begin{tabular}{lcrrrrrr}
\hline $\begin{array}{l}\text { Type of } \\
\text { tissue }\end{array}$ & $\begin{array}{c}\text { Sample size } \\
\text { (No of palms) }\end{array}$ & 1 & 2 & 3 & 4 & 5 & 6 \\
\hline Bark & 42 & 17 & 2 & - & 18 & 5 & - \\
Stem & 106 & 29 & 2 & - & 47 & 3 & 25 \\
Roots & 105 & 13 & 1 & 75 & 5 & 10 & 9 \\
Bleeding + & & & & & & & \\
Brackets & & 11 & 2 & - & 10 & 3 & 9 \\
Bark & 35 & 11 & 29 & - & 8 & 4 & 2 \\
Stem & 51 & 3 & 4 & - & 3 & - & 4 \\
Roots & 14 & 5 & 6 & - & 6 & 7 & 1 \\
Brackets & 25 & & & & & & \\
\hline
\end{tabular}

Key - 1. Fusarium sp. $\quad$ 2. Ganoderma sp. $\quad 3$. Hymenomycetes sp.
4. Penecillium sp. 5. Trichoderma sp.
6. No growth 
Isolation of pure cultures of Ganoderma from basidiocarps produced in affected palms confirmed the association of this pathogen in palms of second category (palms with bleeding and brackets). In these palms extensive root and basal stem decay was evident.

However, no fungi suspected to cause stem bleeding or basal stem decay in coconut were isolated from the first category of palms except in two palms. The two palms yielded pure cultures of Ganoderma sp. from root, bark and stem tissues, which suggest that these palms might have been infected by Ganoderma, although fruiting bodies were not produced. Two types of Hymenomycetes spp. (IMI numbers 375256 and 375257) were isolated from the dead roots of the palms of the first category.

Ganoderma is a serious pathogen of oil palm, coconut and arecanut in Malaysia and India (Singh 1991, Bhaskaran et al., 1989). The symptoms produced by the second group of palms are similar to those produced by Ganoderma spp. on coconut in India (Bhaskaran et al., 1989). A characteristic symptom of Ganoderma disease is stem bleeding followed by decaying of stem base. This symptom was rarely observed in palms having extensive bleeding in Hambantota District. But, Ganoderma was not isolated from the affected tissues in this group, which had only extensive bleeding. Hymenomycetes spp. were also isolated from the dead roots of healthy palms in disease free area. Therefore, involvement of Ganoderma sp. or Hymenomycetes spp. as the primary cause for extended stem bleeding in this group can not be confirmed.

Presence of bleeding palms bordering water bodies suggests the following

1. Fluctuating water table in the channels and in the low-lying areas may affect the physiology of palms and in the process the cell walls are probably damaged, leading to oozing of sap and weakening the tissues.

2. Salinity and other chemicals in water may damage the cell walls or weaken the tissues causing the palms to bleed.

3. Paddy cultivation is done extensively in Hambantota District. Weedicides and fertilizer are applied regularly and those could be washed away with rain and irrigation water. Frequent exposure of coconut roots to weedicides and high concentration of inorganic fertilizer may cause stem. bleeding.

These causes that would weaken palms may predispose them to Ganoderma infections. Therefore, it is essential to determine the role of water 
in causing stem bleeding and predisposing the palms to Ganoderma infection for successful control of the disease in the area.

\section{ACKNOWLEDGEMENTS}

We are grateful to the officers of the Plant Pathology Division of Rubber Research Institute for their assistance during the study period. We thank officers of Coconut Cultivation Board and Coconut Research Institute and Goviniyamaka in Hambantota District for their help in conducting the survey and collecting samples. We appreciate the cooperation of the Director General and staff of Department of Agriculture. Deputy Director Research and officers of Angunakolapelessa Research station kindly assisted us to conduct laboratory work at the research station. Soils and Plant Nutrition Division of Coconut Research Institute kindly analyzed the water samples.

\section{REFERENCES}

Ariffin, D. and Idris, S. (1991) The Ganoderma selective medium. PORIM Information Series. Palm Oil Research Institute of Malaysia, Serdang, Malaysia.

Bhaskaran, R., Retinam, P. and Nambiar, K.K.N. (1989) Thanjavur Wilt of Coconut. J. of Plantation Crops 17 (2) 69 -79.

Goonawardena, H. (1955) Stem Bleeding of Coconuts. Ceylon Coconut Quarterly VI: 89 - 96.

Neelakanthan Potty, N. and Radhakrishnan, T.C. (1978) Stem Bleeding Disease of Coconut - Nutritional Relations. PLACROSYM I Indian Society of Plantation Crops, Kasaragod, Kerala, India.

Peries, O.S. (1974). Ganoderma Basal Stem Rot of Coconut: A New Record of the Disease in Sri Lanka. Plant Dis. Reptr. 58 (4), 293 - 295.

Salgado, M.M. (1942) Notes on Physiological Stem Bleeding of Mature Coconut Palm. Trop. Agric. 98: 31 - 35.

Singh, G. (1991) Ganoderma - The Scourge of Oil Palm in the Coastal Areas. The Planter 67 (786), 421 - 444. 